\title{
Pengaruh Ukuran Perusahaan, Growth, Dan Npm Terhadap Struktur Modal \\ (Pada Sektor Perdagangan Jasa dan Investasi Yang Terdaftar di BEI Tahun 2017-2019)
}

\author{
Dhariif Kholifah', Dirvi Surya Abbas ${ }^{2}$, Mohamad Zulman Hakim \\ Universitas Muhammadiyah Tangerang ${ }^{1,2,3}$ \\ Koresponden Email : dhariifkholifah255@gmail.com
}

\begin{abstract}
Abstrak: Tujuan dari penelitian ini untuk menguji pengaruh ukuran perusahaan, Growth, dan Net Profit Margin terhadap struktur modal Perusahaan perdagangan jasa dan investasi yang terdaftar di (BEI). Periode waktu penelitian yang digunakan adalah 3 tahun yaitu periode 2017-2019. Populasi penelitian ini meliputi perusahaan sektor perdagangan jasa dan investasi yang terdaftar di Bursa Efek Indonesia (BEI) periode 2017-2019. Teknik pengambilan sampel yang digunakan adalah dengan metode purposive sampling. Berdasarkan hasil kriteria yang telah ditentukan maka diperoleh 14 perusahaan yang terdaftar di Bursa Efek Indonesia (BEI) periode 2017-2019.Jenis data yang digunakan adalah data sekunder yang diperoleh dari Bursa Efek Indonesia. Analisis penelitian ini menggunakan regresi data panel. Hasil penelitian menunjukkan bahwa Growth berpengaruh positif signifikan terhadap struktur modal, sementara ukuran perusahaan dan Net Profit Margin tidak berpengaruh terhadap struktur modal.
\end{abstract}

Kata kunci : Ukuran Perusahaan (Size), Growth, NPM, Struktur Modal (DER)

Struktur modal adalah perbandingan atau imbangan pendanaan jangka panjang perusahaan yang ditunjukkan oleh perbandingan hutang jangka panjang terhadap modal sendiri (Martono dan Harjito, 2013:256). Menurut (Devi.et al.,2017) Struktur modal adalah perbandingan antara pemakaian modal pinjaman yaitu utang jangka pendek yang bersifat tetap, utang jangka panjang dengan modal sendiri yaitu saham preferen dan saham biasa. Dalam penentuan struktur modal, sebuah perusahaan harus memikirkan dan memperhatikan macam-macam variabel yang mempengaruhinya karena secara langsung keputusan struktur modal akan mempengaruhi kondisi dan nilai perusahaan juga menentukan kemampuan perusahaan agar tetap bertahan dan berkembang.

Sulitnya manajer keuangan dalam menentukan struktur modal yang optimum bagi perusahaan membuat manajemen lebih menyukai pemanfaatan hutang, ketimbang penerbitan saham baru sebagai pendanaan eksternal perusahaan. Hal ini disebabkan oleh karena adanya penggunaan hutang sebagai sumber pendanaan justru akan memberi tax benefit bagi perusahaan, karena biaya bunga yang ditimbulkan oleh hutang justru merupakan biaya yang dapat mengurangi besarnya pembayaran pajak, sehingga perusahaan mampu menekan jumlah pajak penghasilan perseroan yang disetorkan kepada negara. Perusahaan sektor perdagangan besar berpengaruh bagi perkembangan perekonomian Indonesia. Namun disisi lain perusahaan sektor ini cukup rentan jina nilai rupiah mengalami pelemahan. Berdasarkan informasi yang dilansir dari (Kompas.com-13/05/2018) menyatakan bahwa, 
pelemahan rupiah cukup berpengaruh terutama pada sektor perdagangan besar seperti barang-barang mewah, peralatan elektronik, dan barang kebutuhan lain yang memiliki kandungan impor tinggi. Selain itu, dilihat dari sisi kenaikan suku bunga, sektor ini juga cukup rentan karena memiliki kredit perbankang untuk kegiatan usaha maupun kredit konsumsi oleh konsumen.

Ukuran perusahaan merupakan faktor penting yang menjadi pertimbangan didalam mengambil keputusan yang berkaitan dengan struktur modal. Ukuran perusahaan dapat mempengaruhi struktur modal karena semakin besar ukuran suatu perusahaan akan cenderung menggunakan hutang yang lebih besar. Perusahaan dengan ukuran yang besar cenderung memiliki penjualan yang tinggi (Riski Ayu Pratiwi Batubara, dkk, 2017). Menurut penelitian (Fatimatuz Zuhro MB dan Suwitho, 2016) ukuran perusahaan berpengaruh signifikan terhadap struktur modal, namun menurut (Novi Puji Rahayu \& Prijati 2019) ukuran perusahaan tidak berpengaruh terhadap struktur modal.

Pertumbuhan perusahaan didefinisikan sebagai perubahan tahunan dari total aktiva. Peningkatan asset yang diikuti peningkatan hasil operasi akan semakin menambah kepercayaan pihak luar terhadap perusahaan. Dengan meningkatnya kepercayaan pihak luar (kreditur) terhadap perusahaan, maka proporsi penggunaan sumber dana hutang semakin lebih besar daripada modal sendiri. Hal ini didasarkan pada keyakinan kredituratas dana yang ditanamkan kedalam perusahaan dijamin oleh besarnya asset yang dimiliki perusahaan (Martono dan Harjito, 2013: 133). Menurut penelitian (Fatimatuz Zuhro MB dan Suwitho, 2016) Pertumbuhan perusahaan tidak berpengaruh signifikan terhadap struktur modal, namun menurut penelitian, namun menurut penelitian (Novi Puji Rahayu dan Prijati 2019) pertumbuhan perusahaan tidak berpengaruh suginifikan terhadap ukuran perusahaan.

Tujuan utama dari perusahaan adalah mendapatkan profit sebesarbesarnya. Dengan adanya tujuan tersebut, maka semua kegiatan operasional perusahaan berfokus pada bagaimana perusahaan dapat menghasilkan keuntungan dan aset yang besar. Menurut penelitian (Fatimatuz Zuhro MB dan Suwitho, 2016) Net Profit Margin berpengaruh signifikan terhadap struktur modal, namun menurut (Nova Andriyani Ammudi, 2020) Net Profit Margin tidak berpengaruh signifikan terhadap struktur modal.

Grand teori yang mencangkup pada jurnal ini adalah Pecking Order Theory. Pecking Order Theory mengemukakan adanya urutan sumber dana dalam pembuatan keputusan pendanaan perusahaan. Berdasarkan teori ini, ketika perusahaan membutuhkan dana untuk keperluan pembiayaan investasi dengan dana internal terlebih dahulu. Jika keperluan untuk investasi tidak bisa didapat dari pendanaan internal, maka perusahaan akan menggunakan pendekatan eksternal dari utang sebagai sumber pendanaan kedua, dan ekuitas sebagai sumber pendanaan terakhir. Teori ini membuat perusahaan tidak mempunyai 
target kas optimal, sehingga perusahaan akan cenderung menyimpan sisa kas dari hasil kegiatan oprasionalnya (Jinkar, 2013).

Adapun tujuan dari penelitian ini adalah untuk membuktikan secara empiris pengaruh ukuran perusahaan, pertumbuhan perusahaan (GROWTH), dan net profit margin (NPM) terhadap struktur modal.

\section{METODE}

Penelitian ini merupakan jenis penelitian deskriptif dan kasual komparatif yang menekankan terdapat hubungan sebab akibat antara dua variabel atau lebih yang menjelaskan hubungan antara variabel independen dengan variabel dependen. Teknik pengambilan sampel pada umumnya dilakukan dengan metode purposive sampling, penggunaan data menggunakan instrumen penelitian, analisis data bersifat kuantitatif dengan tujuan untuk menguji hipotesis yang telah ditetapkan. Dalam penelitian ini, teknik analisis data yang digunakan adalah analisis regresi data panel dengan bantuan software pengolah data statistik yaitu Eviews 9.0.

\section{HASIL}

1. Analisis Statistik Deskriptif

Hasil Analisis statistik deskriptif pada masing-masing variabel yaitu, DER, GROWTH, NPM, dan SIZE adalah sebagai berikut:

\begin{tabular}{lcccc}
\hline \hline & DER & GROWTH & NPM & SIZE \\
\hline \hline Mean & 7676.810 & 1162.762 & 1466.857 & 286539.2 \\
Median & 5358.000 & 884.0000 & 1126.500 & 288887.5 \\
Maximum & 42858.00 & 5411.000 & 9524.000 & 310374.0 \\
Minimum & 949.0000 & -583.0000 & 105.0000 & 262234.0 \\
Std. Dev. & 8657.322 & 1238.612 & 1597.686 & 14491.50 \\
Skewness & 2.900564 & 1.916457 & 3.152445 & -0.017867 \\
Kurtosis & 10.97533 & 6.929675 & 16.43341 & 1.880494 \\
& & & & \\
Jarque-Bera & 170.2031 & 52.73376 & 385.3642 & 2.195500 \\
Probability & 0.000000 & 0.000000 & 0.000000 & 0.333621 \\
& & & & 12034648 \\
Sum & 322426.0 & 48836.00 & 61608.00 & $8.61 \mathrm{E}+09$ \\
Sum Sq. Dev. & $3.07 \mathrm{E}+09$ & 62900554 & $1.05 \mathrm{E}+08$ & 42 \\
Observations & 42 & & & 42 \\
\end{tabular}

Sumber : Data Diolah

Gambar 1. Analisis Statistik Deskriptif

Pada tabel diatas, dapat dejalskan bahwa jumlah data yang digunakan dalam penelitian ini sebanyak 42 data. 
Nilai Mean terbesar dialami oleh variable SIZE, yaitu sebesar 286539.2 sementara variable GROWTH memiliki nilai Mean yang paling kecil, yaitu sebesar 1162.762 .

Nilai Median terbesar dialami oleh variable SIZE, yaitu sebesar 288887.5 sementara variable GROWTH memiliki nilai Median yang paling kecil, yaitu sebesar 884.0000 .

Nilai Maximum terbesar dialami oleh variable SIZE, yaitu sebesar 310374.0 sementara variable GROWTH memiliki nilai Maximum yang paling kecil yaitu 5411.000.

Nilai Minimum terbesar dialami oleh variable SIZE, yaitu sebesar 262234.0 sementara variable NPM memiliki nilai Minimum yang paling kecil yaitu 105.0000 .

Nilai Std. Dev terbesar dialami oleh variable SIZE, yaitu sebesar 14491.50 yang berarti bahwa variable SIZE memiliki tingkat risiko yang lebih tinggi mengalami perubahan dibandingkan variable - variable yang lain selama periode penelitian. Sementara variable NPM memiliki nilai Std. Dev yang paling kecil yaitu 1597.686. Hal ini menunjukkan bahwa variabel DER dan GROWTH selama periode penelitian mengalami perubahan yang tidak terlalu fluktuatif.

Skewness dari suatu distribusi simetris (distribusi normal) adalah 0 (nol). Variable DER, GROWTH dan NPM memiliki nilai diatas 0 (nol) yang berarti bahwa asimetri distribusi data sekitar mean bersifat tidak normal, sementara variabel SIZE memiliki nilai variabel disekitar 0 (nol) maka asimetri distribusi data sekitar mean bersifat normal.

Kurtosis mengukur ketinggian suatu distribusi. Kurtosis suatu data berdistribusi normal adalah 3. Untuk variable DER, GROWTH dan NPM memiliki nilai kurtosis lebih dari 3 yang berarti bahwa ketinggian distribusi data tidak normal, sementara variabel SIZE memiliki nilai kurtosis kurang dari 3 yang berarti bahwa ketinggian distribusi data normal.

2. Pemilihan Model Regresi Data Panel

a. Uji Chow

Redundant Fixed Effects Tests

Equation: EQ01

Test cross-section fixed effects

\begin{tabular}{lrrr}
\hline \hline Effects Test & Statistic & d.f. & Prob. \\
\hline \hline Cross-section F & 51.934992 & $(13,25)$ & 0.0000 \\
Cross-section Chi-square & 139.961882 & 13 & 0.0000 \\
\hline \hline
\end{tabular}

Gambar 2. Uji Chow

Sumber : Data Diolah 
Berdasarkan hasil perhitungan diatas nilai Probabilitas Cross Section < 0,05 maka dapat disimpulkan bahwa Fixed Effect Model (FEM) lebih layak digunakan dibandingkan Common Effect Model (CEM).

b. Uji Hausman

Correlated Random Effects - Hausman Test

Equation: EQ01

Test cross-section random effects

\begin{tabular}{lrrr}
\hline \hline Test Summary & $\begin{array}{l}\text { Chi-Sq. } \\
\text { Statistic }\end{array}$ & Chi-Sq. d.f. & Prob. \\
\hline \hline Cross-section random & 4.361689 & 3 & 0.2250 \\
\hline \hline
\end{tabular}

Gambar 3. Uji Hausman

Sumber : Data Diolah

Berdasarkan hasil perhitungan diatas nilai Probabilitas Cross-Section random > 0,05 maka dapat disimpulkan bahwa Random Effect Model (REM) ) lebih layak digunakan dibandingkan lebih layak digunakan dibandingkan Fixed Effect Model (FEM).

c. Uji Lagrange Multiplier

Lagrange Multiplier Tests for Random Effects

Null hypotheses: No effects

Alternative hypotheses: Two-sided (Breusch-Pagan) and one-sided (all others) alternatives

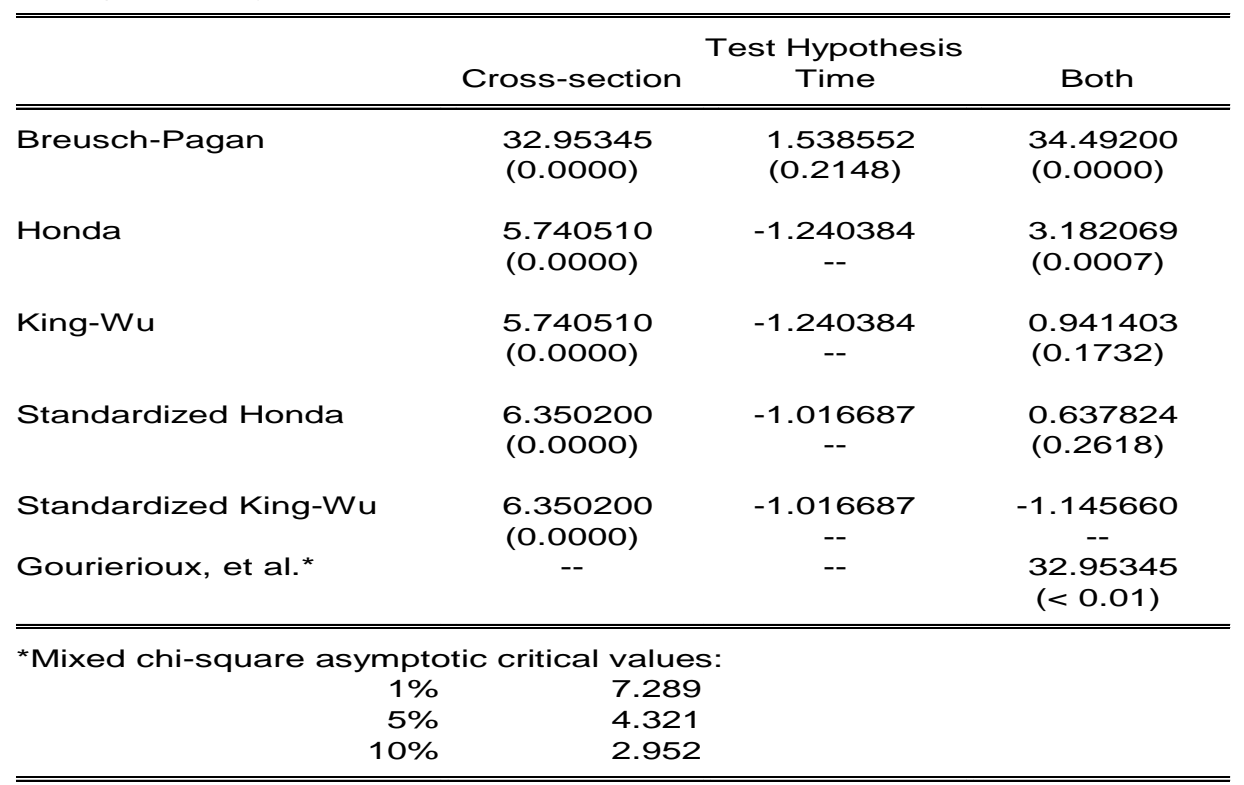

Gambar 4. Uji Hausman

Sumber : Data Diolah 
Berdasarkan hasil perhitungan diatas nilai Probabilitas Cross-Section Breusch-Pagan < 0,05 maka dapat disimpulkan bahwa Random Effect Model (REM) ) lebih layak digunakan dibandingkan lebih layak digunakan dibandingkan Common Effect Model (CEM).

3. Uji Hipotesis

a. Uji Kelayakan Model (Uji F)

$$
\begin{array}{ll}
\text { F-statistic } & 3.637717 \\
\text { Prob(F-statistic) } & 0.021144
\end{array}
$$

Gambar 5. Uji Kelayakan Model (Uji F)

Sumber : Data Diolah

Pada Output diatas menunjukkan bahwa nilai $F$-statistic sebesar 3.637717, sementara $F$ tabel dengan tingkat $\alpha=5 \%$, df1 $(\mathrm{k}-1)=3$ dan df2 $(\mathrm{n}-\mathrm{k})=38$ didapat $\mathrm{F}$ tabel sebesar 2.85. Dengan demikian F-statistic (3.637717) > F Tabel (2.85) dan nilai Prob(Fstatistic) $0.021144<0.05$ maka dapat disimpulkan bahwa variablevariable independen dalam penelitian ini yang terdiri dari Pertumbuhan Perusahaan (GROWTH), Net Profit Margin (NPM), dan Ukuran Perusahaan (SIZE) terhadap Struktur Modal (DER).

b. Koefisien Determinasi

R-squared

0.22311

Adjusted R-squared

$0.1617 \varepsilon$

Gambar 6. Koefisien Determinasi

Sumber : Data Diolah

Pada output diatas menunjukkan bahwa nilai adjusted R-squared sebesar 0.161780, artinya tidak ada hubungan sama sekali antara variabel independen terhadap variabel.

c. Uji t

\begin{tabular}{crrrr}
\hline \hline Variable & Coefficient & Std. Error & t-Statistic & Prob. \\
\hline \hline C & -63130.09 & 43639.12 & -1.446640 & 0.1562 \\
GROWTH & 0.969190 & 0.337356 & 2.872903 & 0.0066 \\
NPM & -0.400941 & 0.338914 & -1.183017 & 0.2442 \\
SIZE & 0.245230 & 0.152378 & 1.609351 & 0.1158 \\
\hline \hline
\end{tabular}

Gambar 7. Uji t

Sumber : Data Diolah

Pada table di atas menunjukkan bahwa :

1. Nilai t-statistic Pertumbuhan Perusahaan (GROWTH) sebesar 2.872903 sementara $t$ Tabel dengan tingkat $\alpha=5 \%$, df $(n-k)=38$ didapat nilai t Tabel sebesar 2.02439. Dengan demikian t-statistic 
GROWTH (2.872903) > t Tabel (2.02439) dan nilai Prob. $0.0066<$ 0,05 maka dapat disimpulkan bahwa variable Pertumbuhan Perusahaan (GROWTH) dalam penelitian ini memiliki pengaruh terhadap Struktur Modal. Dengan demikian, $\mathrm{H} 1$ dalam penelitian ini diterima.

2. Nilai t-statistic Net Profit Margin (NPM) sebesar 1.183017 sementara $\mathrm{t}$ Tabel dengan tingkat $\alpha=5 \%$, df $(n-k)=38$ didapat nilai $t$ Tabel sebesar 2.02439. Dengan demikian t-statistic NPM $(1.183017)<\mathrm{t}$ Tabel (2.02439) dan nilai Prob. $0.2442>0,05$ maka dapat disimpulkan bahwa variable Net Profit Margin (NPM) dalam penelitian ini tidak memiliki pengaruh terhadap Struktur Modal Dengan demikian, $\mathrm{H} 2$ dalam penelitian ini ditolak.

3. Nilai t-statistic Ukuran Perusahaan (SIZE) sebesar 1.609351, sementara $\mathrm{t}$ Tabel dengan tingkat $\alpha=5 \%$, df $(n-k)=38$ didapat nilai $\mathrm{t}$ Tabel sebesar 2.02439. Dengan demikian t-statistic SIZE $(1.609351)<\mathrm{t}$ Tabel (2.02439) dan nilai Prob. $0.1158>0,05$ maka dapat disimpulkan bahwa variable Ukuran Perusahaan (SIZE dalam penelitian ini tidak memiliki pengaruh terhadap Struktur Modal Dengan demikian, H3 dalam penelitian ini ditolak.

\section{DAFTAR PUSTAKA}

Silitonga, D. J. (2019). Pengaruh Likuiditas, Ukuran Perusahaan, Pertumbuhan Penjualan, dan Profitabilitas Terhadap Struktur Modal Perusahaan Manufaktur yang Tercatat di Bursa Efek Indonesia Periode Tahun 2012-2014. Asian Journal of Innovation and Entrepreneurship, 4(2), 139-150.

Chasanah, N. W. S., \& Satrio, B. (2017). Pengaruh Profitabilitas, Likuiditas dan Ukuran Perusahaan terhadap Struktur Modal pada Perusahaan Transportasi. Jurnal IImu dan Riset Manajemen (JIRM), 6(7).

ARILYN, E. J. (2016). Pengaruh managerial ownership, institutional ownership dan rasio keuangan terhadap struktur modal pada sektor perdagangan jasa dan investasi. Jurnal Bisnis dan Akuntansi, 18(1), 43-52.

Zuhro, F. (2016). Pengaruh ukuran perusahaan, pertumbuhan aset, dan profitabilitas terhadap struktur modal. Jurnal IImu dan Riset Manajemen (JIRM), 5(5). 